\title{
Sad shires and no man's land: First World War frames of reference in the British media representation of the Iraq and Afghanistan Wars
}

\begin{abstract}
The focus of this article is the manner in which media representations in Britain of the twenty-first century conflicts in Iraq and Afghanistan drew upon the references, allusions and imagery of the First World War. The application of these visual and textual frames of reference have been used to demonstrate the failings of government, the need for national support or the validation of anti-war perspectives. Through the use of a critical discourse analysis, this assessment will highlight how the war of 1914-1918 is used within contemporary Britain as a vehicle for political and social commentary upon the actions of authority. Despite being fought at the outset of the last century, the newspaper coverage of the British Army's operation in Iraq and Afghanistan demonstrates how the First World War still goes on within sections of British society.
\end{abstract}

Keywords: First World War, Discourse, Britain, Iraq, Afghanistan 


\section{Sad shires and no man's land: First World War frames of reference in the British media representation of the Iraq and Afghanistan Wars}

The First World War still possesses a significant, emotive power in some former combatant countries, despite the passing of time and the death of the last veterans. In Australia, Britain, Canada and New Zealand, to mention the Somme, Ypres, Gallipoli or Vimy is to almost automatically evoke images of blasted war landscapes, atrocious trenches and dugouts all inhabited by piteous soldiers suffering the maelstrom of industrialised war at the behest of an indifferent or incompetent military and political elite. In Britain, these sentiments have been reiterated within popular culture, as film, television programmes and literature have all sought to represent the 'rats, gas, mud and blood' image of the war. Such perceptions have been frequently critiqued by historians over the last two decades as they seek to revise the 'popular memory' of the conflict. In their assessment, the war of 1914-1918 was a 'forgotten victory', a moment when society was mobilised for the war effort, the economy was transformed and the army was triumphant in the field. To understand why within Britain the image of suffering and trauma should hold sway over the wider public consciousness, rather than the concept of noble sacrifice, revisionist historians have sought to assert that the 'popular memory' of the war is a product of media consumption.

In this interpretation, the war poetry and memoirs of such literary figures as Siegfried Sassoon, Wilfred Owen or Robert Graves are regarded as providing a skewed perspective on the First World War. Their foundational work, which focuses on suffering, futility and disillusion, are considered to be a product of a psychologically-thwarted, well-educated, middle class background which was not representative of the wider sentiment within the British Army. Scholars have examined how this disenchanted literature attracted a great deal of sympathy in the turbulent interwar period. The accessibility and popularity of these representations saw it cement a place as 'the war' within British society during the 1930s regardless of the limitations of the authors and their work. Indeed, despite this restricted interpretation, the sentiments of the war poets have come to dominate popular depictions of the war since their publication through a variety of cultural forms. From the 1963 dramatic production of Oh! What a Lovely War to the television programme Blackadder Goes Forth and the novels Regeneration and Birdsong, the same motifs of absurdity and brutality can be distinguished (Korte 2001). The similarity in these representations has led to the assessment that the war is entirely remembered within Britain through the media which has separated the history from the memory of the war.

In Britain, with the preparations for the centenaries of the outbreak, battles and the denouement of the war this disparity between the popular memory and academic history of the conflict has become politicised with accusations of bias and ulterior agendas in how the hundredth anniversaries of the conflict should be marked. The issues at stake were highlighted by the comments in support of the revisionist perspective of the war made by the Conservative MP Michael Gove, Secretary of State for Education, in January 2014: 
The war was, of course, an unspeakable tragedy, which robbed this nation of our bravest and best. But even as we recall that loss and commemorate the bravery of those who fought, it's important that we don't succumb to some of the myths which have grown up about the conflict. Our understanding of the war has been overlaid by misunderstandings, and misrepresentations which reflect an, at best, ambiguous attitude to this country and, at worst, an unhappy compulsion on the part of some to denigrate virtues such as patriotism, honour and courage.

This assessment of the representation of the war as 'myths' perpetuated by the media was immediately countered by critics who stated in turn that such interpretations of the conflict as an exemplum of nobility and loyalty in British society were similarly coloured by political connotations. Such debates emphasise that despite being fought at the outset of the last century, the war still evidently possesses significance within British society. However, as the memory of the war becomes a battleground itself with rival groups seeking dominance in their interpretations, the assessment of the conflict's legacy within British society can be somewhat eclipsed. The debates surrounding the revision of the conflict as a victory or as a tragedy serves to neglect how the war actually functions within contemporary British life. The effect and affect of referencing the conflict evidences how the First World War possesses a social and political utility. Such conceptions of place and meaning are not developed by simplistic assessments of social and cultural memory emphasised in the revisionist debates.

Therefore, rather than assume society vapidly consumes media representations but actively selects particular, favoured visions over others, a nuanced examination of the 'value' of the First World War within contemporary Britain can be enabled. If media, whether film, television programmes, literature or newspapers are regarded not as a directive but as a means of expression for society then the way in which war 'still goes on' can be assessed. This can be demonstrated in how the conflict of 1914-1918 is evoked not directly in the print media but as a means to understand current socio-cultural and political issues. This usage of the conflict can be observed across modern British newspapers, where the war serves as a means to highlight concerns regarding authority, power and responsibility. In this fashion, referring to parties as in 'the trenches' regarding reform or left in 'no man's land' by a negligent institution, using 'the Somme' as a byword for ill-fated or ill-planned ventures or referencing the poetry of Sassoon and Owen to highlight pity or irresponsibility enables a critical engagement with current affairs. These allusions and discussions of the First World War can be regarded as a socially-accepted frame of reference as it requires a knowing and engaging readership. This utility of the conflict is in its employment as an illustrative device, not as a cliché, but as a means of expressing public opinion was most clearly demonstrated in the reporting of the Afghanistan War (2001-2014) and the Iraq War (2003-2011) in Britain.

The deployment of British troops in operations as part of the 'War on Terror' was a highly contested subject within political and social life across the nation. In response to Britain's role in the invasion of Afghanistan and Iraq, these debates were conducted through wide variety of media which were mobilised both in support and against such actions. However, what marked these debates, which covered the initial announcements of war, the nature of the wars' objectives, the tactical and logistical pursuance of victory and the denouement of both conflicts, was the manner in which the First World War was evoked as a 
means to support, counter and critique. Such references appeared as direct visual or textual analogies, comparative pieces, allusions to the war's cultural legacy or the employment of terms associated with the events of 1914-1918. This 'war of representation' was conducted in the tabloids and broadsheets from 2001 to 2014, as the operations in Afghanistan and Iraq garnered divisive opinions. This usage of the First World War appears to counter the revisionist argument that the conflict's popular perception as 'mud, blood, rats and gas' is derived from its media representation. In this example, the conflict was used as both a conservative and dissenting factor in the accounts of the development of the 'War on Terror'. Such applications of this frame of reference emerged from the media itself but also through newspapers from politicians and the wider public alike. Therefore, the appearance of such references indicates a far more complex use of the heritage of the First World War within British society. Politics, power, place and identity are all mobilised with the mention of the war of 1914-1918 and these sentiments were drawn upon to create frames of reference for the conflicts in Iraq and Afghanistan.

These frames of reference can be regarded as the product of social and political relations which indicate the values and ideals of society (Goffman 1974). These relations can be identified through the application of a critical discourse analysis (CDA) that reveals the wider meanings of the First World War (after Fairclough 1995; 2001). This approach recognises that the application of discourses is purposeful and possesses social and political effect. Therefore, the analysis of discourse, whether visual or textual, forms a means of identifying values and perceptions within a group, community or society (after Bakhtin 1986: 121). CDA is a significant method of analysing the discourses used in society to understand how this means of representation structures experience (Fairclough 2001: 15). This approach is based upon the identification of the function and value of communication (after Fairclough 2003: 26). Each of these particular themes highlights the complex interaction that occurs between representation and consumption. With the agenda defined by CDA, the discourses used within any media do not represent a prescriptive demand upon society to view an issue in a particular manner but a means through which society defines itself.

To clarify the approach taken with CDA, Fairclough and Wodak (1997: 271-278) highlighted a series of fundamental tenets to describe and guide the application of the technique:

- CDA addresses social problems

- Power relations are discursive

- Discourse constitutes society and culture

- Discourse does ideological work

- Discourse is historical

- The link between text and society is mediated and interpreted

- Discourse analysis is explanatory

- Discourse is a form of social action

In this approach, CDA examines discourse, whether textual or visual, as emerging within specific socio-political contexts that define a particular historical era. Therefore, by examining how a community represents issues, the language used, the imagery that is drawn or the subtext that is present, an insight into how that community assesses the significance of 
an event or concern can be stated. At the centre of these debates is the operation of power within society through discourse; the ability to control and organise discourse evidences a high degree of authority but it also ensures that discourse itself becomes a means of resistance to that authority. Through the framing, position and identification within discourses the operation of power can be evidenced and challenged (Fairclough 2003: 26). Indeed, by defining phrases, allusions, references and motifs, CDA demonstrates the latent, hegemonic structures of control within society as well as revealing the dissonant voices that emerge through that same mode of representation.

Analysing the output from British newspapers from 2001 to 2014 that draws upon the conflict of 1914-1918 to report on the 'War on Terror', demonstrates how the media does not shape opinion on the First World War but serves as a mirror for observing how society uses the war to understand contemporary issues. Within the context of the centenaries of the conflict during 2014 to 2018, the place of the war within contemporary British society will be placed under greater scrutiny. The manner and form of the remembrance activities will be assessed for their political neutrality or bias whilst the popular understanding of the war will be challenged and revised. However, the complexities of the heritage of the war for British society lie beyond such simplistic examinations. Through the examination of the way in which the First World War is used to assess and frame current issues, the public perception of the conflict can be assessed as more than a vapid consumption of film and television.

Through the media reporting of the Iraq and Afghanistan wars, using the framework provided by such phrases as 'in the trenches', 'no man's land', 'over the top' or representing the war within the context of Owen or Sassoon's poetry, the place and value of the events of 19141918 can be observed. Indeed, within these references, allusions and comparisons, the war 'still goes on' for contemporary British society. This is not the result of a nostalgic, sentimental vision of the war brought about by viewings of Oh! What a Lovely War or readings of Birdsong. It is evoked because the conflict is used as a symbolic resource, to affirm or to challenge current issues. During the Afghanistan and Iraq Wars, such uses of the past served to emphasise how the meaning of the First World War was interpreted and reimagined rather than fixed in purpose.

\section{In the trenches, a war of attrition and home by Christmas}

In 2006, the cartoonist Steve Bell, publishing in The Guardian newspaper, highlighted the problems faced by the British government in policing and developing Afghanistan after the international coalition's invasion of the country in 2001 (Bell 2006). With the caption 'In Afghanistan it's not "going over the top", it's "reconstruction with extreme prejudice", Bell sets the scene with the then Defence Secretary Dr John Reid standing in the trenches in the Afghan desert, whistle ready, whilst lines of soldiers line up by a ladder ready to move up. Accompanied by such strong connotations to the war of 1914-1918, including the trench setting and the call to go 'over the top', the cartoon offers a means of placing the current conduct of the British Government in the critical context of the operations of the First World War. Issues of blame, responsibility and incompetence are thereby immediately attached to the operation of government. The use of the First World War in this fashion is significant; it demonstrates how the war serves as a critical device in the reporting of the wars in Afghanistan and Iraq. 
This use of allusions to the First World War, to the 'trenches' or 'trench warfare' operates as a means to heighten emotional and political responses in order to or censure military or civilian authorities for their policies in the 'War on Terror'. In these accounts, newspaper reports evoked the imagery of the 1914-1918 war and specifically the battlefields of the Western Front in critical pieces which decried the tactics and the progress of operations. For example, The Scotsman reported in January 2007 of the incredulity of troops occupying trenches in Afghanistan; 'Almost 100 years after WWI, British troops have returned to the trenches' (Cumming 2007). Similarly, Michael White (2010), writing in the Guardian newspaper in May 2010 evoked the 'bloodier existential conflict' on the Western Front to highlight the failings of the 2003 invasion of Iraq. In this mode of representation, the First World War serves as a frame to situate an understanding of the war in Afghanistan. Therefore, news reports entitled 'All Quiet on Afghanistan's Western Front' recall more than the state of current operations in the field (North 2005). This use of explicit or implicit references to 'the trenches', to denote the conditions faced by troops in modern-day Afghanistan and Iraq, offers a means of critique. For example, the court case launched by veterans of the British Army for foot injuries sustained in tours of service was specifically linked in some media outlets to the wounds sustained in 'trench warfare' by British First World War soldiers. Such references were used to highlight issues of negligence and the irresponsibility of the British Government in failing to protect its troops at a time when the level of fatalities in Iraq and Afghanistan were severe:

About 150 troops, many from Commonwealth countries, are seeking compensation after sustaining the modern equivalent of trench foot (Ingham 2009).

The Ministry of Defence said today it regretted any physical suffering caused by the condition - similar to the infamous First World War "trench foot" - and would pay out where liable (Bentham 2009)

The inclusion of 'the trenches' serves as an intensifier of emotions: a means to emphasise the absence of care towards the ordinary man in the field. The association with the perceived victimhood of the soldiers of the First World War is used within the reporting of the war within the popular press as a mode of judgement. The comparison frames the contemporary conflicts in Afghanistan and Iraq as comparable to the events of 1914 to 1918. Indeed, this association can be made directly in some cases, such as the following extract from The Observer newspaper, which published extracts from letters written by a front line British soldier serving in the Helmand Province in 2009:

We got smashed the other day, mate, and got pinned down in a compound 150 metres from the base. We fired the Javelin to cover our withdrawal but had to wait 10 minutes for smoke again - fucking criminal. I can honestly say mate I was fucking terrified and now know what the blokes went through waiting for the whistle in the trenches in WW1 (Anon 2009) 
Similarly, the Glasgow newspaper The Herald made the same unequivocal comparison with its reporting of the British soldiers experiences in 2003:

Iraq War Diary: It was more like a scene from the Somme...Rain and mud make life a misery on the front line with the Black Watch near Basra (Bruce 2003).

In November 2001, at the outset of the war in Afghanistan, a report in Scotland on Sunday featured an interview with Scotland's last veteran of the First World War, Alfred Anderson, whose experiences were used to warn of the folly of war:

But as a nation remembers the millions of men slaughtered on the battlefields of France and Belgium, Anderson's thoughts are on the present-day conflict consuming lives on a different continent (Young 2001).

In this manner, the First World War can be regarded as a spectre, haunting the representation of the Afghanistan and Iraq Wars (after Derrida 1993). However, this presence is far from an immaterial, ghostly apparition; rather, it serves as a corrective device, calling into account the actions of authority. The usage of the expression 'war of attrition' is particularly significant in this regard. The phrase emerged during the First World War to describe the tactics employed by the Allied and Central Powers as each sought a means to break through the opposing lines of trenches. As an idiom particularly associated with the impasse on the Western Front, it has been especially significant as a means to politicise and to criticise the recent wars in Afghanistan and Iraq where British troops have been deployed in a longstanding engagement against insurgents. The expression appears to constitute a lament in this context, as the protracted and costly nature of the contemporary military operations in the two warzones became abundantly clear as the wars progressed. Within the print media, describing military, political or civilian experiences in Afghanistan or Iraq as a 'war of attrition' thereby emphasises a perception of the conflict as a bloody, pointless endeavour which has no end in sight. The war is in this sense reported in the framework provided by the conflict of 19141918:

They will blunder on, not to a clean defeat but to something far worse, a war of attrition whose poison will spread across a subcontinent (Jenkins 2003).

The war of attrition in Iraq continued its bloody course yesterday with at least 63 people killed, including a busload of soldiers who died when a roadside bomb exploded in the northern city of Beiji' (Beresford 2006).

These allusions do not indicate the repetition of media clichés in the reporting of the war but an active engagement with the memory of the First World War in the comprehension of the present. Rather than being derived from a passive consumption of media, the use of the imagery, allusions and associations from the war of 1914-1918 serves to emphasise how the memory of the conflict is used within society as a vehicle of protest and dissent. Such a mobilisation can be further evidenced with the reporting of former Prime Minister Tony 
Blair's comments in 2004 that the Black Watch Regiment, deployed to the so-called 'Triangle of Death' near Fallujah in Iraq, would be 'home by Christmas'. This statement, made as part of a speech in the House of Commons in October 2004, was immediately placed by opponents within the context of the First World War. The 'hauntological' quality of August 1914 is observed here as the phrase 'home by Christmas' has become associated with the short-sightedness or incompetence of the British military and political elite that assured volunteers that the war would be a short, adventurous escape from civilian life (after Halifax 2010). These connotations implied by the phrase were heavily exploited within the popular press. Indeed, writing in the Daily Mail, the columnist Peter Hitchens emphasised his incredulity that such a term could be employed:

Nobody who knew any history would have used this ominous phrase, recalling as it does the claim that the First World War would be 'all over by Christmas' in 1914. Would to God that it had been, but wars are not like that. We should all pray that the Black Watch are indeed home by Christmas. But I do not see how Mr Blair can make this promise (Hitchens 2004).

Similarly, the Independent newspaper drew attention to the connections between the phrase and how it offered a cruelly ironic presage to a far more damaging and horrendous military engagement:

In 1914 men rushed to enlist, fearful they would miss the "adventure" unfolding in Belgium and France...in return for a promise that the men would be "home by Christmas". Four years later the survivors returned from the front, with 8.5 million of their comrades dead (Elliot et al 2004).

However, the notion that troops would be 'home by Christmas', replete with its association with August 1914, is not restricted to this one incident. The phrase is repeatedly utilised throughout the period of military engagement, especially in reference to the operation of British troops in Iraq, to emphasise the duplicity, ineptitude or indifference of the British authorities. By 2006, the journalist Robert Fisk uses the inaccuracy of the phrase to illustrate the 'march of folly that has led to a bloodbath' in Iraq (Fisk 2006). This critical employment of the claim that troops would be soon home after a short engagement abroad is further evidence of the active use of the memory of the war. The continued use of the term demonstrates its capacity to serve as a means of indicting the policies of the British Government. In 2006, the Daily Telegraph reported on the war in Iraq through this specific frame of reference:

Home by Christmas? Make that 2010 at least (Harding 2006)

Whilst in 2009, the London Evening Standard reused the phrase in an article by their Defence Correspondent, Robert Fox, which examined the seemingly endless and potentially fruitless pursuit of victory in Iraq, affirming the connection between the expression and notions of ineptitude: 
In April 2003 he pitched some 40,000 British servicemen and women into southern Iraq in the belief that, like the Tommies going to war in August 1914, they would be home by Christmas. The facts on the ground soon revealed that the British and Americans were in a land and facing a people they did not understand and could not possess - and had landed themselves with huge and unexpected problems of governance and security.

Despite the varying political hues of British newspapers, the employment of First World War frames of reference to examine the contemporary Afghanistan and Iraq Wars was conducted in the same critical manner. This similarity in form does not entail the homogenous, medialed remembrance criticised by some commentators, it highlights how the war of 1914-1918 is used by social and political groups to advance arguments and to understand the present.

\section{No man's land in Iraq and Afghanistan, sad shires in Britain}

The use of First World War frames of reference in the reporting of the First World War is not solely conducted within a dissident political agenda. Indeed, the conflict of 1914-1918 can be observed to be mobilised throughout the wars in Iraq and Afghanistan to support the cause of the British Government and to emphasise the endeavour of the British Army. Such conservative perspectives undermine the oft-quoted argument from revisionist historians that the popular memory of the war has emerged from left-leaning media representations. Indeed, in this manner the newspaper reporting of the war demonstrates that the First World War operates as a symbolic resource that can be drawn upon to reiterate a range of viewpoints and agendas. This is clearly illustrated with the employment of the term 'no man's land' with reference to the operations conducted within the 'War on Terror' as well as wider references to the battlefield landscapes of the First World War. The purpose of such allusions is significant as it immediately places the current soldiers of the British Army in connection to the sympathetic figure of the 'Tommy in the trenches'. Writing in the conservative newspaper, the Daily Mail, Colonel Richard Kemp, a former Commander serving in Afghanistan, utilised this association in November 2009 as he reflected upon the recent death of a soldier in Helmand Province. Highlighting how the soldier had served in the same regiment as Harry Patch, the last veteran of the First World War, a direct association between the conflicts are made to present the heroic virtues of the armed forces:

From the muddied fields of Agincourt to the quagmire hell of the Somme to the dry plains of Afghanistan, the British soldier has overcome his opponents in countless campaigns (Kemp 2009).

This mode of reporting the sacrifices and endeavours of the modern army within the context of the First World War operates to negate the criticisms of what was a highly contentious decision to involve British troops in operations in Afghanistan and Iraq as part of a multinational coalition. This can also be evidenced in the reporting of the tour of duty of Afghanistan taken by Prince Harry in 2008. Indeed, favourable reports of the third in line to the British throne focused on the similarity of the experience of the 'soldier prince' with his 
ordinary predecessors who fought in the First World War. Prince Harry compared the two warzones directly in an interview:

The whole place is just deserted, there are no roofs on any of the compounds, there are craters all over the place, it looks like something out of the Battle of the Somme (Hickley 2009).

Such a means of representing the contemporary conflicts through the compassionate frame of the war of 1914-1918 is illustrated with the use of 'no man's land' in newspaper reports. This term, with its origins in the fourteenth century, is most clearly associated in Britain with the First World War on the Western Front in France and Flanders. It is 'no man's land' which appears to be so redolent of the suffering of soldiers in the trenches and its use in recent newspaper reporting of the 'War on Terror' serves to emphasise a degree of solidarity with the work of British soldiers in Iraq and Afghanistan:

Major Alex Turner, an Old Etonian who read war studies at King's College London, has been awarded a medal for his pioneering work that led to insurgents being forced out of a "no man's land" in Helmand (Mansey 2011).

Scots sniper Harry Black stares through his rifle sight into no-man's land. Eight hundred metres in front of the 24-year-old Lance Corporal is the enemy... the Taliban (Hamer 2010).

The use of no man's land in this manner also accompanied the reports of Prince Harry's deployment to the warzone in Afghanistan. In this representation, the third in line to the throne was depicted as 'occupying' or 'surveying' 'no man's land'. The effect of such a discourse is to ensure that the Prince of Wales is depicted as an ordinary soldier; an everyman whose experiences on the front lines evoke the sympathy of support granted to the 'Tommy in the trenches':

And with nerves of steel he declared: “It's just no-man's-land. They poke their heads up and that's it." Yet at the time he was just three weeks into his posting (Hughes 2008).

Harry was posted to the operations room at Forward Operating Base Delhi, the southernmost Allied outpost in Helmand. It's a stone's throw away from "Line Arbroath", the frontline that looks on to a 500-metre area of No-Man's land (Anon 2008).

Such reporting serves to normalise both the Prince of Wales as an 'ordinary soldier' but to garner support and sympathy for the conflict that the British Army have been detailed to fight. The media accounts that fuse the landscape of the First World War with that of Helmand or Basra offer a means to reflect on the heroism and sacrifice of the troops but not necessarily the cause for which they serve. Therefore, accounts of soldiers in the field that 
occupy the 'trenches' or 'no man's land' do not necessarily condemn military authorities, rather acknowledge the efforts undertaken by the armed forces. For example, the following account of a soldier in Afghanistan in 2007 published in the Daily Mirror equates the environment of the Western Front with the endurance of modern British soldiers:

Days later, he was part of a patrol on "Taliban Hill", overlooking the no-man's land between the coalition-run area and the "green zone" held by the terrorists. A Taliban mortar exploded in a cloud of black smoke just five metres from Marine Dodsworth, but he was saved by a crumbling mud and straw wall. "You can't train for that," he says. "But we know we can't run scared. You have to get on with the job" (Lyons 2007).

The use of the imagery of the First World War to support the efforts made in Afghanistan and Iraq by the British Army illustrate how the conflict of 1914-1918 does not occupy one single meaning or another. Rather, its use in reports concerning the 'War on Terror', demonstrate a variety of functions, from dissent towards authority to support and sympathy for the soldiers serving in the theatres of war. What is distinct about this process is that regardless of the cause for which the First World War is mobilised, it is done so with the intent to highlight contemporary concerns. Therefore, the imposition of the war landscape of 'no man's land' to frame perceptions can be compared to the use of the imaginative landscape of the war poets of Siegfried Sassoon and Wilfred Owen in British newspaper reporting. Articles and editorials examining the military action in the regions of Helmand and Basra during the deployment of British troops from 2001 to 2014 were frequently placed within the framework provided by the war poets of 1914-1918. The use of this reference provided an opportunity to draw upon the tragic, piteous image of the war to highlight issues of neglect and irresponsibility by the authorities but also the callous, futile waste of war. For example, during periods of intense operations and a corresponding rise in fatalities amongst coalition troops and civilians in Iraq and Afghanistan, the works of Owen (Anthem for Doomed Youth or Dulce Et Decorum Est or Sassoon (Suicide in the Trenches or The General) could be evoked as a damning indictment of the war:

Every conflict produces its anthem for doomed youth, but this is an elective crusade, fought not in extremis but because of political desires. They call it a humanitarian war. There is no such thing (Riddell 2003).

The old Lie: Dulce et decorum est...That "old lie" being that it is sweet and proper to die for one's country. Though the First World War poets may never be bettered...Their message needs to be applied to Iraq and Afghanistan, lest we become too enamoured with such hazardous pursuits (James 2011).

Whilst the reporting of the wars in Afghanistan and Iraq utilised the themes addressed by Owen and Sassoon, the war poets were also drawn upon as a means to criticise contemporary politicians for their policies; thereby, forming a direct correlation with the presumed incompetence of the political and military elite of the First World War and the present day. 
For example, the journalist John Pilger, writing in the New Statesman, remarked upon former Prime Minister Tony Blair's appearance at the Cenotaph during Remembrance Day in 2003:

Having shown his studied respect to the Queen, whose prerogative allowed him to commit his crime in Iraq, Blair hurried away. "Sneak home and pray you'll never know," wrote Siegfried Sassoon in 1917, "The hell where youth and laughter go" (Pilger 2003).

Such a critical perspective was particularly noticeable with the reports of the arrival back to Britain of the bodies of the dead, those who were killed in the service of their country in Iraq and Afghanistan. As a practised emerged of parading the military funeral cortege through the Wiltshire town of Wootten Bassett, the phrase 'sad shires' from Owen's Anthem for Doomed Youth, was regularly employed to illustrate the scale of death and the 'futility' of war:

Watching this week's vaunted big push in Afghanistan has been infuriating beyond belief, not least because of the latest procession of soldiers' coffins, driven in the rain through sad shires, valuable and irreplaceable lives honourably lost in a rotten cause (Hitchens, 2010).

How apt that seems now as young soldiers return from Afghanistan in coffins and "bugles call for them from sad shires". Sacrifice on nowhere near the same scale of course, but sacrifice all the same (Austen, 2008).

Wilfred Owen's poem of the Great War, "Anthem for Doomed Youth," is deeply embedded in the culture. Among its most haunting line is the one that evokes the home front - "bugles calling for them from sad shires." Wootton Bassett takes that on for this century: it is a sad shire of the national imagination (Leith, 2011).

Rather than merely illustrating the habitual use of clichés and standard illustrative devices within contemporary war reporting, the application of references to the First World War in the reporting of the conflicts in Iraq and Afghanistan is a significant phenomenon. The use of this interpretative framework demonstrates the manner in which the remembrance of the conflict of 1914-1918 is more than the result of a passive acceptance of film, literature and television. Indeed, the newspaper reporting of the 'War on Terror' through allusions to the First World War highlights its significance within British society as a vehicle for popular opinion. In this manner, the war fought at the outset of the twentieth century still goes on as it provides a means of highlighting fears, concerns and debates in the present day. As such, the First World War can be used to understand the conflicts that were fought at the outset of the twenty-first century.

\section{Conclusions}

The application of CDA to the media representation of the Iraq and Afghanistan Wars demonstrates the potential of studying the relationship between war, media and culture through a wider chronological setting. The manner in which articles and editorials from 
British newspapers that engaged with the political, social and military ramifications of the 'War on Terror' utilised the cultural legacy of the First World War was highly evident. This use of references offers a means of engaging with how contemporary conflicts are represented within the spectre of previous military engagements. Scholars have highlighted how the ramifications and aftermath of wars shape future political agendas, a field most aptly highlighted with discussions of the 'Vietnam Syndrome' in the United States. However, this area can be greatly enhanced through studies which seek to catalogue and comprehend the particular tropes and discourses employed in the media reporting of conflicts. Within these descriptions and assessments of war, a subtle interplay of language, politics and power are played out which illustrate wider social values and norms. Within the media reporting of contemporary conflicts, the echoes of past wars and engagements demonstrate more than truisms but a commentary on public and political life.

In the context of the centenary of the outbreak of the First World War in August 2014 as well as the subsequent anniversaries of events, battles and declarations of peace through to 2018, the media representation of the conflict will be crucial in understanding public remembrance. However, rather than assuming that it is television programmes such as Blackadder Goes Forth or revivals of plays such as Journey's End or Oh! What a Lovely War, that is responsible for public perceptions, it is in the use of the conflict as a discursive element that British society's attitudes towards the war can be assessed. The reference, allusion and comparison points taken from the conflict provides a frame of reference which is used to analyse situations from a variety of perspectives, from the dissident to the supportive. The war in this sense has no inherent meaning; it gathers its significance through the manner in which it is applied to contemporary conflicts. This demonstrates how the legacy of the First World War constitutes an active cultural response within Britain. Despite the passing of a century, the conflict can still be evoke with considerable effect. This prominence of the conflict, as illustrated by its use within the wider media regarding the recent wars in Iraq and Afghanistan, ensures that the war will not pass from 'social memory'. Indeed, society will continue to return to 'the trenches' and 'no man's land' as it seeks to imbue symbolism and significance upon contemporary concerns. 